
and Aquatic Sciences

\title{
Spatiotemporal variability in energetic condition of alewife and round goby in Lake Michigan
}

\begin{tabular}{|r|l|}
\hline Journal: & Canadian Journal of Fisheries and Aquatic Sciences \\
\hline Manuscript ID & cjfas-2018-0391.R1 \\
\hline Manuscript Type: & Article \\
\hline Author: & 10 -Dec-2018 \\
\hline Complete List of Authors: & $\begin{array}{l}\text { Bunnell, David; U.S. Geological Survey, } \\
\text { Pothoven, Steven; Great Lakes Environmental Research Lab - NOAA } \\
\text { Armenio, Patricia; U.S. Geological Survey, Great Lakes Science Center } \\
\text { Eaton, Lauren; University of Toledo College of Natural Sciences and } \\
\text { Mathematics } \\
\text { Warner, David; U.S. Geological Survey } \\
\text { Elgin, Ashley ; NOAA, Great Lakes Environmental Research Laboratory } \\
\text { Burlakova, Lyubov; SUNY College at Buffalo } \\
\text { Karatayev, Alexander; Buffalo State College }\end{array}$ \\
\hline Keyword: & $\begin{array}{l}\text { Oligotrophication, calorimetry, COMPETITION < General, FISHERY } \\
\text { MANAGEMENT < General, tributary input }\end{array}$ \\
\hline $\begin{array}{r}\text { Is the invited manuscript for } \\
\text { consideration in a Special } \\
\text { Issue? : }\end{array}$ & \begin{tabular}{l} 
Not applicable (regular submission) \\
\hline
\end{tabular} \\
\hline
\end{tabular}

\section{SCHOLARONE $^{\text {TM }}$ \\ Manuscripts}


1 Spatiotemporal variability in energetic condition of alewife and round goby in

3

4

5

6

7

8

9

10

11

12

13 Toledo, OH, USA

$14{ }^{4}$ Great Lakes Center, SUNY Buffalo State, 1300 Elmwood Avenue, Buffalo, NY 14222, USA

15 *Corresponding author- dbunnell@usgs.gov, Phone: 734-214-9324, Fax: 734-994-8780

16

17 Keywords: oligotrophication, calorimetry, competition, fishery management, tributary inputs 


\section{Abstract}

19 Pelagic-oriented alewife (Alosa pseudoharengus) and benthic-oriented round goby (Neogobius melanostomus) are two important prey fish in the Laurentian Great Lakes. In 2015, we evaluated

21 their seasonal total energy (TE) across nine Lake Michigan transects. Round goby contained at

22 least $48 \%$ more kilojoules of TE than alewife of equal length during spring and summer. TE

23 varied spatially for both species, but only large alewife exhibited a consistent pattern, with higher

24 values along the eastern shoreline. Variation in TE was not explained by site-specific prey

25 densities for either species. Round goby energy density (ED) was higher in Lake Michigan than

26 in central Lake Erie, but comparable to other regions of the Great Lakes. Alewife ED in 2015

27 was similar to 2002-2004 in Lake Michigan, with the exception of November (small alewife ED

28 was 21\% higher) and April (large alewife ED was 30\% lower). Despite oligotrophication, our

29 study suggests that starvation of juvenile and adults has not been directly contributing to overall

30 declining prey fish abundance, although future research should evaluate the potential for

31 overwinter starvation. 


\section{Introduction}

Multiple ecological drivers can influence population dynamics of fish, including

34 predation, climate, pathogens or disease, and limiting resources. In developed countries,

35 watershed management continues to improve in some regions, causing reductions in nutrient inputs to reservoirs and lakes and even reversing some systems from eutrophication to oligotrophication (Stockner et al. 2000; Anderson et al. 2005) and potentially limiting resources

38 for fishes. Disentangling the effects of limiting resources on a fish population can be difficult among the many other drivers in any given system. Estimating the energetic condition of fishes offers one method to determine the extent to which limiting resources could be influencing individual survival and contribute to population dynamics. This method has been applied to

42 address a diversity of research questions in a broad range of ecosystems, including monitoring

43 the recovery of Atlantic cod populations (Lambert and Dutil 1997), overwinter survival and

44 effects on recruitment (Pangle et al. 2004), and understanding community-level interactions

45 between seabirds and their prey fishes (Wanless et al. 2005).

47 undergone or are undergoing oligotrophication owing to long-term declines in nutrient inputs and changes to internal nutrient recycling associated with the proliferation of dreissenid mussels

49 (Evans et al. 2011)- zebra mussels Dreissena polymorpha and then quagga mussels D. bugensis.

50 In Lake Michigan, declines in phytoplankton (Fahnenstiel et al. 2010; Pothoven and Fahnenstiel

51 2013) and Diporeia spp., a high-energy benthic prey resource (Nalepa et al. 2014), are

52 unambiguous, whereas zooplankton have declined in some regions but not in others (Bunnell et

53 al. 2018). Correlation analyses at the lakewide level reveal declining prey fish biomass to be

54 correlated with declines in nutrients, phytoplankton, zooplankton, and benthic invertebrates, but 
more empirical work is required to evaluate whether limiting resources is, in fact, the causal factor (Bunnell et al. 2014). Previous studies have documented declining energy density for different fish species (Hondorp et al. 2005; Madenjian et al. 2006; Rennie et al. 2009; Pothoven et al. 2012; Pothoven and Fahnenstiel 2014), likely resulting from declining Diporeia prey resources. Concerned by declines in phosphorus and phytoplankton, Lake Michigan managers are seeking improved knowledge of how changing lower trophic levels could be contributing to the declining abundance of prey fishes (Bunnell et al. 2018) which, in turn, support a recreational fishery targeting Chinook salmon (Oncorhynchus tshawytscha), lake trout (Salvelinus namaycush), steelhead (Oncorhynchus mykiss), Coho salmon (Oncorhynchus kisutch), and brown trout (Salmo trutta) that invested more than 9 million angler-days of effort in 2015 (U.S. Department of Interior 2016).

In a system as large as Lake Michigan $\left(58,000 \mathrm{~km}^{2}\right.$, spanning 4.5 degrees of latitude), spatial heterogeneity in nutrients and prey resources that ultimately support the piscivores is likely. For example, several tributaries in the southeast corner of the lake occur in agricultural watersheds and have been modeled to deliver relatively high loads of total phosphorus inputs (e.g., Saint Joseph, Kalamazoo, Grand) compared to other regions of the lake (Dolan and Chapra 2012; Robertson et al. 2018). Managers have begun to recognize this spatial variability in their decision making. For example, Michigan Department of Natural Resources is implementing a zonal strategy where they will adjust fisheries management to match available habitat within its more than $34,000 \mathrm{~km}^{2}$ of water that falls within its state boundary (J. Wesley, Michigan Department of Natural Resources, 621 N. 10 ${ }^{\text {th }}$ Street, Plainwell, Michigan, USA, personal communication). One possible outcome is to develop zonal stocking strategies that best reflect optimal thermal habitat or prey availability for a given species. In the Great Lakes, previous 
78 studies rarely have analyzed the energetic condition of prey fishes in a spatial context to evaluate 79 whether locally productive areas can translate into higher energy density for a given fish species. In Lake Michigan, alewife (Alosa pseudoharengus) and round goby (Neogobius

81 melanostomus) are the two prey fishes that most commonly occur in piscivore diets (see Jacobs 82 et al. 2013; Happel et al. 2018). Both species are nonindigenous, although the alewife

83 proliferated several decades earlier than the round gobies (i.e., 1960s versus 2000s). They differ, 84 however in their habitat use, with alewives being benthopelagic (older alewives spend daytime

85 86

87 associated with the bottom and migrate up at nighttime, Janssen and Brandt 1980) and round gobies being benthic. Alewife energy density (ED, typically in kilojoules (kJ)/g wet mass) has been well studied at the lakewide level. Madenjian et al. (2006) reported a 23\% decline in ED for large alewife between 1979-1981 and 2002-2004, but no change for small alewife. In a more recent study focused on yearling alewife from a transect in southeastern Lake Michigan, Pothoven and Fahnenstiel (2014) reported lower ED in 2010-2013 than in 1998-1999, as well as steeper declines in first-year overwinter ED in the later years compared to the earlier ones. Both studies attributed the declining ED to declines in Diporeia prey, which themselves declined precipitously following the proliferation of dreissenid mussels. Round goby ED, conversely, has not previously been described in Lake Michigan so temporal comparisons are not possible. But we can compare round goby ED in Lake Michigan to other studies in a Lake Michigan watershed (Ruetz et al. 2009), in Lake Huron (Steven A. Pothoven, Great Lakes Environmental Research Laboratory-National Oceanic and Atmospheric Administration, 1431 Beach St, Muskegon, MI, USA, unpublished data), and in central Lake Erie (Johnson et al. 2005). 
In this paper, we compare the total energy (TE) content for the two primary prey fishes in

102 Lake Michigan, alewife and round goby. For each species, we will then evaluate the spatial

103 variability in TE across 9 nearshore to offshore transects that putatively differ in their

104 productivity given variable proximity to tributaries with different levels of phosphorus input.

105 We hypothesize that TE values will be positively related to densities of their primary prey (i.e.,

106 zooplankton for alewife, quagga mussels for round gobies). Finally, we compare the 2015 ED of

107 alewives and round gobies to previous Lake Michigan studies and studies in other regions,

108 respectively. Given the declining benthic and pelagic resources for alewife (e.g., Diporeia and

109 cladoceran zooplankton) in Lake Michigan, we hypothesize that alewife ED will be lower in

1102015 than in previous years. For round goby, given that Ruetz et al. (2009) showed higher ED in

111 a Lake Michigan tributary than in central Lake Erie, we hypothesize that the relatively high

112 abundance of quagga mussel prey in Lake Michigan proper will enable the ED of Lake Michigan

113 round gobies to be similar to what Ruetz et al. (2009) reported.

\section{Methods}

Alewives and round gobies were collected through bottom and midwater trawling from

117 nine transects around Lake Michigan (Fig. 1), some of which were adjacent to tributaries with

118 historically high phosphorus loading (e.g., St. Joseph, Manitowoc, Kalamazoo; Dolan and

119 Chapra 2012). At each transect, trawling occurred over multiple bottom depths (ranging $9 \mathrm{~m}$ to

$120128 \mathrm{~m}$ ) and at least three times during 2015, targeting spring (April 16 - May 11), summer (July

121 18-26), and autumn (October 18-November 3). The standard bottom depths that were sampled

122 during each targeted season and at all sites were 18, 46, and either 91 or $110 \mathrm{~m}$. At some sites,

123 opportunistic fish collections were made at additional depths along the Pere Marquette, 
124 Waukegan, Frankfort, and Sturgeon Bay transects during September 13-26, and at the standard 125 depths along the Muskegon transect on May 27, June 30, and August 31. Aboard the research 126 vessel, fishes were sorted by species and processed to obtain a total weight (by species) and up to 12750 measurements of total length (TL, by species). Alewife and round goby were frozen in water 128 within 30 minutes of capture, and maintained in a $-20{ }^{\circ} \mathrm{C}$ freezer until processed. These two fish species were not captured in each transect in each season.

To estimate $\%$ dry weight $(\% \mathrm{DW})$, fish were thawed, measured for TL (nearest $\mathrm{mm})$ and intact wet weight (nearest $0.1 \mathrm{~g}$ ). For alewives, stomachs were excised to prevent biased 132 estimates of \%DW or ED, although any fat attached to the stomach was scraped off and kept with the rest of the tissue for drying. For round gobies, we discarded the contents of the 134 digestive tract, but did not remove the stomach tissue. For both species, individual fish were cut 135 into several $\sim 20$-mm pieces and placed into a tin that was pre-weighed to the nearest $0.0001 \mathrm{~g}$.

136 The wet weight of the dissected fish was then estimated to the nearest $0.0001 \mathrm{~g}$, and this was the 137 value used to estimate $\% \mathrm{DW}$. Individuals were dried in an oven at $65^{\circ} \mathrm{C}$ until a constant weight 138 (nearest $0.0001 \mathrm{~g}$ ) was achieved. Fish were first weighed after 48 hours, and then every 24 hours 139 thereafter. The time to reach a constant weight ranged from 72 to 216 hours. Hence, for each 140 individual fish, \%DW equaled (dry weight/dissected wet weight)*100\%. A subsample of fish was selected for direct ED estimation, for which \%DW is a strong 142 predictor (Hartman and Brandt 1995). The subsampled fish were selected to represent a 143 distribution of fish sizes from each transect and season and were homogenized with either a 144 coffee grinder or mortar and pestle, the latter being used more for smaller amounts of dried 145 tissue. For alewives less than $100 \mathrm{~mm}$, we combined up to 6 fish that were within $10 \mathrm{~mm}$ TL of 146 one another to make a composite sample for direct ED estimation. For round gobies, composites 
147 of similar sized fish were made if individual fish were less than $0.2 \mathrm{~g}$ dry weight. From either

148 the sample of composited fish or an individually ground fish, up to a 1-g subsample of dried

149 tissue was combusted in a Parr 1261 isoperibol bomb calorimeter that was standardized with

150 benzoic acid. ED was converted to joules per gram of wet weight using the known dry weight :

151 wet weight ratio for that fish. For composite samples, the dry weight : wet weight ratio for a fish

152 equaled the sum of dry weights divided by the sum of the dissected wet weights across the

153 individuals used. Triplicate ED estimates were made for 10 alewife and 10 round goby to

154 estimate within-sample variability. Because the mean coefficient of variation $[100 \times(\mathrm{SD} / \mathrm{mean})]$

155 was less than $1 \%$ among replicates, only a single estimate was made for the remainder of the ED

156 determinations.

157 The relationship between ED (kJ/g wet weight) and \%DW was determined for each

158 species, and used to predict ED for individuals where only \%DW was known. For alewives, ED

159 vs. $\%$ DW was examined separately for small (i.e., $\leq 120 \mathrm{~mm}$ TL) and large (i.e., >120 mm TL)

160 sizes, following the size classes used by Madenjian et al. (2006). For round goby, the best

161 predictive relationship for ED was found when the data were not split into size classes. For the

162 analyses seeking to explain variation in ED, however, we divided the round goby data into two

163 size classes $($ small $=\leq 70 \mathrm{~mm}$ TL and large $=>70 \mathrm{~mm}$ TL) because there was such a strong

164 positive relationship between fish size and ED for small round gobies.

Does total energy differ between alewife and round goby?

167 Total energy (TE, in $\mathrm{kJ}$ ) for each fish was calculated as the ED (either estimated directly 168 or calculated from $\% \mathrm{DW}$ ) multiplied by the dissected wet weight of the fish. Because energetics 169 of alewives vary seasonally (see Madenjian et al. 2006), we analyzed each season separately for 
170 both species. Because the variance in total energy increased with fish size, we ln-transformed

171 both ED and TL in the model when estimating the relationship with linear regression. The

172 coefficient of determination $\left(R^{2}\right)$ in $1 n$-space revealed the variability in total energy for a given

173 length, in each species and season. We also reported the predicted mean total energy $(\widehat{T E})$ in

174 arithmetic space:

$$
\widehat{T E}=e^{\left(\alpha+\beta \ln (T L)+\frac{M S E}{2}\right)}
$$

where $\alpha$ and $\beta$ equal the intercept and slope of the ln-transformed regression, and MSE equals the

177 mean square error of the regression (Hilborn and Walters 1992). We compared ( $\widehat{T E}$ ) for a

178 "small" (i.e., $100 \mathrm{~mm}$ TL) and "large" (i.e., $150 \mathrm{~mm}$ TL) fish for each species and season.

Does total energy vary spatially within species?

When summarizing data from a given transect in each season, we required energy

182 estimates from at least five fish for a given size class for spatial analyses. We conducted an 183 Analysis of Variance (ANOVA) to determine whether the residual TE (observed TE - predicted $184 \mathrm{TE}$ ) differed across transects. Because the variance in TE increased with fish size, the residuals were calculated in ln-space. Because previous studies have separately analyzed size classes of 186 alewife, and because diets can differ with ontogeny for both alewives and round gobies (e.g., 187 Bunnell et al. 2015), we conducted a separate ANOVA for each species, season, and size class. When TE varied among transects, we conducted Bonferroni t-tests for pairwise comparisons 189 between transects.

For the month with the largest number of transects for a given fish and size class, we used

191 Pearson's correlation to explore whether the mean residual TE was associated with prey 192 availability: zooplankton biomass for alewife or quagga mussel biomass for round gobies (see 
193 below). This analysis occurred in October for small alewife ( $\mathrm{N}=6$ transects $)$ and small and 194 large round gobies $(\mathrm{N}=9$ transects). No correlative analysis was possible for large alewife 195 because of limited sample size: the month with the largest number of transects (July) only had an $196 \mathrm{~N}=4$ because comparable zooplankton data were not available for Muskegon. When prey 197 availability was non-normally distributed, we performed a natural log transformation to improve 198 normality. To represent alewife prey availability, we averaged both total and "consumed" (taxa = Epischura lacustris, Bythotrephes longimanus, Limnocalanus macrurus, Bosmina spp.,

201 Leptodiaptomus sicilis, Diacyclops thomasi) zooplankton across summer and autumn months

202 from the $18 \mathrm{~m}$ and $46 \mathrm{~m}$ sites, because we assumed that small alewives were not yet born when 203 zooplankton were sampled in the spring and no small alewives were sampled at the $110 \mathrm{~m}$ site.

204 For our study, we based "consumed" zooplankton on the zooplankton taxa that occurred in at 205 least $10 \%$ of the diet for a give size class in a recent Lake Michigan diet study (Bunnell et al. 206 2015). During spring, summer and autumn at the $18 \mathrm{~m}$ and $46 \mathrm{~m}$ sites for each transect, 207 zooplankton were sampled at night with a $153-\mu \mathrm{m}$ mesh, 0.5-m diameter, conical net that 208 vertically sampled the water column from $2 \mathrm{~m}$ above the bottom to the surface. A flowmeter that 209 was calibrated during each season was mounted within the mouth to estimate total distance 210 sampled such that $\mathrm{m}^{3}$ of water sampled could be estimated. Samples were preserved in 5\% 211 buffered formalin after first being narcotized with antacid. In the laboratory, the entire zooplankton sample was first inspected for aggregations of 213 large predatory cladocerans (i.e., Bythotrephes, Cercopagis) that could affect subsampling; when 214 aggregations were found, smaller crustacean zooplankton were disentangled and larger predatory 215 cladocerans were removed for subsequent processing. The zooplankton sample was then diluted 
216

217

218

219

220

221

222

223

224

225

226

227

228

229

230

231

232

233

234

235

236

237

238

with reverse-osmosis water to between $30-750 \mathrm{~mL}$, with the goal of attaining a concentration of 200 zooplankters per mL. After mixing the sample with a glass rod, a 1-mL aliquot was removed with a Hensen-Stempel pipette. All individual crustacean zooplankton from the subsample were identified to the highest taxonomic resolution possible (see below) and counted under a dissecting microscope; copepod nauplii, dreissenid veligers, and rotifers were not enumerated because we believed their densities would be biased too low because of the $153-\mu \mathrm{m}$ mesh of the net. All adults were identified to species (except for Bosmina spp.) and copepodites (immature copepods) were identified to genus in a few instances (e.g., Mesocyclops, Tropocyclops, Limnocalanus, Epischura, Senecella) but were otherwise identified as either calanoid or calanoid copepodites. If 200 or more zooplankters were counted in the first aliquot, no additional ones were processed. Otherwise, aliquots were removed in 1-mL increments and processed as described above until at least 200 individuals (total) were counted. The entire sample (including any aggregations that were previously removed) was then processed to enumerate predatory cladocerans, noting the instar for Bythotrephes and Cercopagis. For all taxa, up to the first 20 individuals encountered were measured using an ocular micrometer, and biomass was estimated using published, taxa-specific length/weight regressions. We calculated the total and preferred crustacean zooplankton biomass for each sampling depth in each season. To represent round goby prey availability, we used quagga mussel biomass (i.e., no zebra mussels were found in 2015; Karatayev and Burlakova 2017) rather than zooplankton given the predominance of dreissenid mussels in round goby diets (Kornis et al. 2012). Although smaller round gobies (i.e., $<75 \mathrm{~mm} \mathrm{TL}$ ) do not consume as many dreissenid mussels as larger ones, a Lake Michigan diet study in 2010 still reported dreissenids as comprising between 16 and 49\% of the diet, depending on the season (Bunnell et al. 2015); other prey that dominated the diets of 
239

240

241

242

243

244

245

246

247

248

249

250

251

252

253

254

255

256

257

258

259

260

261

small round gobies in at least one season were Eurycercus lamellatus and ostracods, but density estimates for those benthic prey were unavailable. Benthic invertebrates were sampled with a ponar grab (sampling area $=0.048 \mathrm{~m}^{2}$ ) during the summer (only) along each of our transects. At each site, three replicate ponar samples were collected, sieved through a $0.5-\mathrm{mm}$ mesh, and preserved in $10 \%$ buffered formalin. In the laboratory, all dreissenid mussels were removed from the sample sediment with the aid of a dissection microscope, identified to species, and then shell length was measured to the nearest $1 \mathrm{~mm}$. The mussels were aggregated within 5-mm size fractions: $0-5 \mathrm{~mm}, 5-10 \mathrm{~mm}$, up to $35-40 \mathrm{~mm}$. Within each size fraction, the mussels were blotted dry to remove excess moisture, then weighed to the nearest $0.001 \mathrm{~g}$. Thus, biomass is expressed in terms of whole mussel wet weight, which includes soft tissue and shell. We reported biomass of mussels $\leq 15 \mathrm{~mm}$ because round gobies are gape limited in the size of mussel they can consume (Djuricich and Janssen 2001). Diet data from a 2010 diet study (Bunnell et al. 2010) revealed that $99.6 \%$ of mussels consumed had a shell length of $15 \mathrm{~mm}$ or less, which corresponds with other published field studies (Djuricich and Janssen 2001; Andraso et al. 2011). We averaged quagga mussel biomass $\left(\mathrm{g} / \mathrm{m}^{2}\right)$ sampled from sites $<46 \mathrm{~m}$; all small round gobies in autumn were collected at 18 and $46 \mathrm{~m}$ depths and although $23 \%$ of large round gobies were collected at $110 \mathrm{~m}$ we assumed their migration to these deeper waters had occurred very recently (e.g., Walsh et al. 2007) and previously were feeding at shallower depths.

\section{Comparing alewife and round goby energy density to previous studies}

Madenjian et al. (2006) estimated the monthly ED from small and large alewives sampled from 8 sites in Lake Michigan in 2002-2004 and compared their ED to those estimated in 19791981. For April, May, July, September, and November, we determined whether the $95 \%$ 
262 confidence intervals in our mean alewife ED overlapped with the 95\% CI reported by Madenjian

263 et al. (2006) for 2002-2004 or with the energy density schedule reported by Madenjian et al.

264 (2006, see Figure 2) from Stewart and Binkowski (1986) and Hewett and Johnson (1992) from 265 1979-1981.

266

267 ED versus wet weight relationship. These include round goby from the Muskegon River,

268 Michigan watershed in 2004 (Ruetz et al. 2009), Lake Huron in 2007, and central Lake Erie from 269 1995-2002 (Johnson et al. 2005).

270

271 Results

Percent dry weight was a strong predictor of alewife ED $\left(r^{2}=0.97, P<0.0001\right.$,

273 Table 1). Alewife ED was directly estimated from 582 individuals or composites, and calculated 274 from $\% \mathrm{DW}$ for another 524 individual fish. Alewife ED was weakly positively correlated with 275 fish size. For the 286 small alewives (i.e., $\leq 120 \mathrm{~mm}$ TL) across all transects and seasons, ED 276 increased with TL, but only $12 \%$ of the variation was explained $\left(F_{1,284}=40.0 ; P<0.0001 ; r^{2}=\right.$ 277 0.12). For the 820 large alewives, ED was even less related to TL $\left(F_{1,818}=63.0 ; P<0.0001 ; r^{2}=\right.$ $2780.07)$.

280 relationship was not as strong as observed for alewife and analyzing the data by size class did not 281 improve the fit. Round goby ED was directly estimated from 585 individuals or composites, and 282 indirectly estimated from another 644 individuals. The relationship between ED and TL differed 283 between size classes (see Fig. 2b). For small round gobies (i.e., $\leq 70 \mathrm{~mm}$ TL) ED increased 284 strongly with TL $\left(F_{1,447}=161.1 ; P<0.0001 ; r^{2}=0.26\right)$. For larger round gobies, there was a 
285 statistically significant relationship between ED and fish size $\left(F_{1,777}=13.1 ; P=0.0003 ; r^{2}=\right.$

286

287

288

289

290

291

292

293

294

295

296

297

298

299

300

301

302

303

304

305

306

0.02), but probably not ecologically meaningful.

\section{Does total energy differ between alewife and round goby?}

Given that TE is the product of WW and ED, we plotted how these two variables were related to fish length for each species. For WW, round gobies always weighed more than alewife at a given TL (Fig. 2a) with the predicted weight for a $100-\mathrm{mm}$ round goby $(14.3 \mathrm{~g}$ ) being $71 \%$ greater than for alewife $(6.8 \mathrm{~g})$. For a $150-\mathrm{mm}$ fish, round gobies weighed $64 \%$ more than alewives (51.9 g. vs $26.8 \mathrm{~g}$ ). ED of round gobies did not vary markedly by season, and linearly increased from 20 to $80 \mathrm{~mm}$ TL, and was relatively constant for larger sizes (Fig. 2b). Alewife ED varied both with season and size (Fig. 2b). For alewives smaller than $100 \mathrm{~mm}$, ED also increased linearly among autumn fish, at a much faster rate than for round gobies, and then largely leveled off at larger sizes. For alewives larger than $100 \mathrm{~mm}$, seasonal effects drove the variability with the highest average ED occurring in autumn $(8.1 \mathrm{~kJ} / \mathrm{g})$, followed by spring $(5.0$ $\mathrm{kJ} / \mathrm{g})$ and summer $(4.0 \mathrm{~kJ} / \mathrm{g})$.

During spring, a 100-mm round goby provided about $73 \%$ more TE than a $100-\mathrm{mm}$ alewife (64 kJ vs. $30 \mathrm{~kJ}$, Fig. 3a, b), and for a 150-mm fish, round goby provided 81\% more TE $(273 \mathrm{~kJ}$ vs. $116 \mathrm{~kJ})$. Alewives were more variable in TE for a given size $\left(R^{2}=0.69\right)$ than were round gobies $\left(R^{2}=0.99\right)$. Post-hoc analysis of covariance of the alewife data indicated no difference in total energy between males and females in spring $\left(\right.$ size $\times$ sex: $F_{1,133}=0.67, P=$ 0.41; sex: $\left.F_{1,133}=0.69, P=0.41\right)$. Hence variation in alewife ED for a given size was more likely related to spatial differences or to some other factor that caused variation within a site. 
During summer, round gobies continued to provide more TE than alewives (Fig. 3c, d).

A $100-\mathrm{mm}$ round goby provided $60 \mathrm{~kJ}, 48 \%$ more than a $100-\mathrm{mm}$ alewife $(37 \mathrm{~kJ})$. The difference was $90 \%$ for 150 -mm fishes: $235 \mathrm{~kJ}$ vs. $89 \mathrm{~kJ}$ for round goby and alewife, respectively, although the round goby estimate was an extrapolation. As found for spring, variability across individual alewife as a function of size $\left(R^{2}=0.33\right)$ was extremely high compared to round gobies $\left(R^{2}=0.99\right)$ and differences between sexes did not account for the variability in alewife (size $\times$ sex: $F_{1,133}=0.81, P=0.37$; sex: $\left.F_{1,133}=0.79, P=0.38\right)$. During autumn, differences between round goby and alewife TE were smaller. For 100$\mathrm{mm}$ fish, round gobies provided $66 \mathrm{~kJ}$ of TE whereas alewife provided $53 \mathrm{~kJ}$, a 23\% difference (Fig. 3e, f). For a 150-mm fish, round gobies provided $279 \mathrm{~kJ}$ of TE whereas alewife provided $237 \mathrm{~kJ}$, a $17 \%$ difference. Unlike spring and summer, however, total energy as a function of fish size was just as predictable for alewife $\left(R^{2}=0.98\right)$ as for round gobies $\left(R^{2}=0.98\right)$. This result suggests that for each species, ED for a similarly sized fish was not very different within and across sampling sites during autumn.

\section{Does total energy vary spatially within species?}

For both size classes, mean residuals of alewife TE varied across transects in each season. For small alewife in the spring (likely yearlings), multiple comparisons revealed that residual TE from individuals caught at Frankfort had significantly higher values than those from the Root transect (Fig. 4a), whereas those from Muskegon were not different from the other ones. In autumn, small alewives [likely young-of-year (YOY)] from Waukegan had higher residual TE than those from the Frankfort and Root transects, while those from the other four transects were not different from the other ones (Fig. 4d). For autumn, alewife residual TE was unrelated to 
330 either measure of zooplankton biomass (preferred ZP: $r=-0.77, P=0.07$; total ZP: $r=-0.48, P$ $331=0.34)$.

For large alewife in the spring, those from Frankfort had significantly higher residual TE than those from the Root and Waukegan transects (Fig. 4b). For summer, none were caught

334 from Frankfort but the highest residual TE was found for alewives in southeast Lake Michigan,

335 St. Joseph and Muskegon, which had higher values than those from Sturgeon Bay, Root, and 336 Waukegan (Fig. 4c). By autumn, large alewives from St. Joseph still had the highest residual 337 TE, along with those from Frankfort and Waukegan (Fig. 4e); those from the Root transect had 338 significantly lower residual TE. For large alewife, the highest mean residual TE was generally 339 along the eastern shoreline transects.

For round gobies, the mean residual TE varied across transects in spring and autumn. For small round gobies in spring (likely yearlings), those from Sturgeon Bay had significantly higher

342 residual TE than those from the Root and Waukegan transects (Fig. 5a). In autumn, small 343 (presumably YOY) round gobies were collected from every transect. Those from the Muskegon 344 transects had higher residual TE than those from the Pere Marquette, Kalamazoo, and St. Joseph transects (Fig. 5d); those from the Root and Manitowoc transects also had higher residual TE 346 than those from the Pere Marquette.

347 Large round gobies in spring were classified into three groups whose mean residual TE 348 differed from one another (Fig. 5b). Those from Sturgeon Bay had the highest residual TE, 349 followed by those from Manitowoc, Root, Pere Marquette, Waukegan, and Frankfort, and then 350 those from St. Joseph had the lowest residual TE. In summer, large round gobies were only 351 collected from two transects (Waukegan and Muskegon) and their residual TE was not different 352 from one another (Fig. 5c). In autumn, large round gobies from Manitowoc had a higher mean 
353 residual TE than those from Sturgeon Bay, Frankfort, Pere Marquette, Kalamazoo, and St.

354 Joseph transects (Fig. 5e). Curiously, large round gobies from Sturgeon Bay were the highest

355 residual TE in spring but then dropped to among the lowest residual TE in autumn. Round goby

356 residual TE in autumn was not related to quagga mussel biomass for either the small $(r=-0.05, P$

$357=0.89)$ or large $(r=-0.47, P=0.21)$ size classes.

358

359

Comparing alewife and round goby energy density to previous studies

Alewife ED differed from previous studies more for small individuals than large ones.

361 For small alewife, ED could only be compared with previous studies for late fall. ED in early

362 November 2015 averaged $6.5 \mathrm{~kJ} / \mathrm{g}$ wet mass, which was $21 \%$ and $23 \%$ higher than estimated in

363 2002-2004 and 1979-1981, respectively (reported by Madenjian et al. 2006). Conversely, large

364 alewife ED has not increased relative to earlier time periods. In fact, the $95 \%$ confidence

365 intervals overlapped between 2015 and 2002-2004 for May, July, September, and November

366 (Fig. 6a). In April, the intervals from the two time-periods differed, and large alewife ED was

$36730 \%$ lower in 2015 than in 2002-2004. Averaging the ED of large alewife in 2002-2004 and

3682015 and comparing to 1979-1981 reveals the steepest declines occurred in April and May (30-

$36938 \%$ ) and that ED in autumn (September and November) was only 17\% lower in the 2000s than

370 in 1979-1981 (Fig. 6b).

371

Round goby ED (kJ/g wet mass) in Lake Michigan in 2015 was best described by the

372 equation $3.646 \times W^{0.0736}$, where $W$ equals the wet weight of the fish. Our data overlapped

373 considerably with the best fit ED reported by Ruetz et al. (2009) in the Muskegon River

374 watershed and for Lake Huron (S. A. Pothoven, unpublished data, Fig. 7). For very small round

375 gobies $(2 \mathrm{~g})$ the percent difference among these three studies was no more than $4 \%$. For a $15-\mathrm{g}$ 
376 round goby, those from Muskegon River watershed study had 10\% greater energy density than

377 our study and those from Lake Huron had 6\% greater energy density than our study. We note,

378 however, that the size range and sample size from our study (range $=0.1-83.5 \mathrm{~g}$, mean $=11.6 \mathrm{~g}$,

$379 \mathrm{~N}=585$ ) was larger than the range from the Muskegon (range $=0.1-16.1 \mathrm{~g}$, mean $=3.3 \mathrm{~g}, \mathrm{~N}=$

380 33) and Huron (range $0.7-23.8 \mathrm{~g}$, mean $=4.3 \mathrm{~g}, \mathrm{~N}=154$ ) studies. Round goby from central

381 Lake Erie included a relatively broad size range (range $=2.0-132.9 \mathrm{~g}$, mean $=31.3 \mathrm{~g}, \mathrm{~N}=46$ )

382 and were larger, on average, than those from our study. However, $91 \%$ of the round goby ED

383 values from 2015 in Lake Michigan were higher than predicted from central Lake Erie. The

384 percent difference between Lake Michigan and central Lake Erie fish declined with size: $60 \%$ for

$3853 \mathrm{~g}, 17 \%$ for $15 \mathrm{~g}, 4 \%$ for $40 \mathrm{~g}$, and no difference by $58 \mathrm{~g}$.

386

387 Discussion

Estimating the energetic content of fishes is a helpful tool to evaluate how resources vary across time or space. Our somewhat surprising result was that during spring and summer, a round goby contained at least $48 \%$ more $\mathrm{kJ}$ of TE for piscivore consumption than an alewife of equal length. By autumn, however, alewife ED had markedly increased and alewife TE was only $17-23 \%$ lower than round goby TE of a similar length. This result demonstrates the variability in energetic content between species, and that round goby have the potential to be even more beneficial to piscivores than alewife from an energetics perspective should the availability of these prey species be equal in terms of length distributions. In terms of spatial variability, both species exhibited variability in TE across transects- especially in spring and autumn (summer comparisons were limited by sample size). For large alewives, the only consistent spatial pattern was higher residual TE along the eastern shoreline (i.e., Frankfort, Muskegon, St. Joseph 
transects). No spatial pattern was evident for small alewives, and variation in residual TE in the autumn was unexplained by their primary prey: zooplankton biomass. Likewise, no spatial pattern in residual TE was apparent for small or large round gobies, nor was the variation explained by their primary prey: quagga mussel biomass less than $15 \mathrm{~mm}$ in length. Pooling round goby ED across our sites in Lake Michigan revealed some spatial variability across the Great Lakes. Round goby ED from central Lake Erie (Johnson et al. 2005) was consistently lower than what we measured in Lake Michigan and Huron or what others have measured in a Lake Michigan tributary (Ruetz et al. 2009). Temporal comparisons of alewife ED in Lake Michigan revealed a 21-23\% increase in 2015 for small alewife in November relative to 20022004 and 1979-1981, and a 30\% decrease in 2015 for large alewife in April relative to 20022004; comparisons between 2015 and 2002-2004 for large alewife revealed no differences in the other months.

Across a broad range of aquatic systems, differences in energy density have been noted among key prey fish species (Rand et al. 1994; Lawson et al. 1998; Anthony et al. 2000; Eggleston and Schramm 2002). These differences can sometimes be explained by guilds. For example, in the northern Gulf of Alaska, schooling pelagic species (analogous to alewife) tended to have either very high or low ED, whereas nearshore benthic species (analogous to round goby) had intermediate ED values (Anthony et al. 2000). Since the invasion of round gobies in the Great Lakes basin, studies have compared round goby with other prey fishes and concluded round goby ED is comparatively average (Ruetz et al. 2009) or among the lowest (Forzono et al. 2017). For example, in the Muskegon River watershed that drains into Lake Michigan, round goby ED was intermediate among four native prey fishes (Ruetz et al. 2009). In the upper Niagara River and Buffalo harbor, round goby ranked among the lowest ED among 15 species 
422 and size classes of prey fishes (Forzono et al. 2017). Had we compared only ED between

423 alewife and round goby, we would have concluded that alewife is higher than round goby in all

424 seasons except summer. But because predators consume the entire fish, an equally appropriate

425 comparison is TE, where fish of similar TL are compared given that TL, rather than weight, is

426 the typical dimension considered when analyzing prey size selection by piscivores (see Juanes

427 1994). Because round goby weighed at least $60 \%$ more than an alewife of equal length, the TE

428 of round goby can be more energetically beneficially to piscivores.

429 Our result that round goby offers more TE than an alewife of equal length has

430 implications for piscivore growth beyond Lake Michigan given that these two species have been

431 important prey species in other systems. From the 1970 s through early 2000 s, alewives were a

432 key prey fish for Chinook salmon and lake trout in lakes Michigan, Huron, and Ontario (Brandt

433 1986; Jude et al. 1987; Diana 1990; Madenjian et al. 1998). Alewife densities have undergone

434 some degree of decline in each of these Great Lakes, even to the point of "collapse" in Lake

435 Huron (Riley et al. 2008). Over this time of alewife decline, round gobies invaded and

436 proliferated everywhere but Lake Superior (Kornis et al. 2012) and their prevalence in piscivore

437 diets has increased (Dietrich et al. 2006; Roseman et al. 2014; Happel et al. 2018). Lake trout,

438 for example, appear to have compensated for declining availability of alewife with more frequent

439 consumption of round goby, and scientists have hypothesized how this substitution can benefit

440 thiamine levels in lake trout eggs and improve their reproductive success (Fitzsimons et al. 2009;

441 Happel et al. 2018). To our knowledge, ours is the first study to suggest that substitution of

442 round goby for alewife also can offer an energetic advantage so long as the lengths of alewife

443 and round goby prey are similar. We caution, however, that the assumption of equal length

444 distributions between the species may not be realized. To illustrate, in each season of our 2015 
445 study, the mean size of alewife sampled in our trawls was always larger than the mean size of 446 round goby $($ spring $=129$ vs. $80 \mathrm{~mm} \mathrm{TL}$, summer $=147 \mathrm{vs} .88 \mathrm{~mm} \mathrm{TL}$, autumn $=98$ vs. $74 \mathrm{~mm}$

447 TL). Assuming a piscivore consumed an average-sized fish, an average alewife provided $85 \%$, $44874 \%$, and $73 \%$ more TE than an average round goby in spring, summer, and autumn of 2015 , 449 respectively. This comparison illustrates the importance of length distributions in determining 450 which of these common Great Lakes prey fishes provides a greater energetic benefit to 451 piscivores. Spatiotemporal variability in TE can indicate differences in quality or quantity of resources available to fish. Alewives were much more variable in TE for a given length in spring and summer than round gobies. One interpretation of this result is that alewives were more

455 resource limited during these seasons than round gobies, perhaps owing to greater spatial 456 variation in the quality or quantity of what is consumed. Perhaps round gobies always have a 457 relatively abundant prey resource, quagga mussels, that contributes to homogenization of TE 458 across the lake for a given length. Conversely, alewife diets may be more diverse, especially 459 when seeking to replace Diporeia, a high-lipid prey item that comprised at least 35\% of large 460 alewife diets in the spring through the mid-1990s (Rand et al. 1995; Davis et al. 2007; Pothoven 461 and Madenjian 2008). Since the decline of Diporeia (Nalepa et al. 2014), alewife spring diets 462 have shifted to include more calanoid copepods and Mysis diluviana (Pothoven and Madenjian 463 2008; Bunnell et al. 2015). We hypothesize that the proportion of mysids in alewife diets could 464 be driving the relatively high variability in TE for a given site, given that mysids are a large and 465 high lipid prey resource. Among the alewife diet studies in Lake Michigan since quagga mussels 466 have become abundant, the percentage of mysids in the diets ranged from 7-51 at different sites 467 and years (Pothoven and Madenjian 2008; Bunnell et al. 2015). Although we did not conduct 
468 diet analyses with the 2015 alewives, we would hypothesize that alewife captured at the 469 Frankfort transect had consumed more mysids during winter into spring, given that alewives 470 from Frankfort had higher than average TE values.

471 We hypothesized that energetic content of fishes would be reflective of spatial or 472 temporal patterns in prey resources. For plantivorous Pacific herring (Clupea pallassii) in Prince

473 William Sound, autumn and winter ED differed among different regions and scientists

474 hypothesized that differences in zooplankton quality and quantity underlie the variation (Paul 475 and Paul 1999; Gorman et al. 2018). Among three southeast Lake Michigan sites in an earlier 476 study, the one with the lowest density of Diporeia spp. prey also had the lowest ED for 477 deepwater sculpin and large alewife (Hondorp et al. 2005). Likewise, lipid levels for Diporeia 478 spp. were higher in northern Lake Michigan than in southern waters (Nalepa et al. 2001), and the 479 authors posited that greater diatom densities in the north could explain the difference. In our 480 study, the strongest spatial pattern occurred with large alewife, where residual TE was 481 consistently higher on the eastern side of the lake (e.g., Frankfort, Muskegon, St. Joseph 482 transects) in each season. The eastern and western shorelines of the lake are known to differ 483 with respect to upwellings (more frequent on the western shore, Plattner et al. 2006), substrate 484 type (rockier and more complex in the lower western two-thirds of the lake, Janssen et al. 2005), 485 and number of high-phosphorus loading tributaries (more on the eastern shore, Dolan and Chapra 486 2012). Recent Lake Michigan diet studies for spottail shiner (Notropis hudsonius) and yellow 487 perch (Perca flavescens) that covered both coastlines indicated more benthic-oriented prey were 488 consumed on the western side and more pelagic-oriented prey were consumed on the eastern side 489 (Happel et al. $2015 \mathrm{a}, \mathrm{b}$ ). Whether more pelagic prey items enhanced the TE of pelagic-oriented 490 alewife on the eastern side of the lake deserves further research. It is logical that the higher 
491 phosphorus loading along the southeastern coastline (i.e., St. Joseph, Grand, Kalamazoo Rivers)

492 could enhance phytoplankton and even zooplankton productivity. However, we found no

493 relationship between residual TE of small alewife in the autumn and coincident zooplankton

494 biomass from the summer and autumn.

Our comparisons of round goby ED from 2015 to other systems indicated (1) minimal

496 differences with those from the Muskegon Lake watershed (Ruetz et al. 2009) and Lake Huron,

497 and (2) round gobies from central Lake Erie generally have a lower ED. This second result is

498 surprising given that central Lake Erie is more productive, in terms of phosphorus and

499 chlorophyll, than Lakes Michigan and Huron (Bunnell et al. 2014). At the same time, densities

500 of dreissenid mussels at comparable depths were considerably higher in Lake Michigan

$501\left(2,053 \pm 697\right.$ per $\mathrm{m}^{2}$ in the $0-30 \mathrm{~m}$ depth range in 2015$)$ than in central Lake Erie $(608 \pm 224$ per

$502 \quad \mathrm{~m}^{2}$ basinwide density in 2014; Karatayev and Burlakova 2017). Lower mussel densities in

503 central Lake Erie are likely due to hypoxia that develops at depths greater than $20 \mathrm{~m}$ and

504 eliminates dreissenids sensitive to low oxygen (Karatayev et al. 2018). At the same time,

505 surveys in 2014-2015 reported densities for non-dreissenid invertebrates such as chironomids

506 and oligochaetes to be more than twice as high in central Lake Erie $\left(11,357\right.$ per $\left.\mathrm{m}^{2}\right)$ than in Lake

507 Michigan (4,618 per $\mathrm{m}^{2}$; Karatayev and Burlakova 2017), and non-dreissenid invertebrates

508 typically have a higher ED than dreissenid mussels (Johnson et al. 2005). Hence two

509 explanations for lower round goby ED in central Lake Erie are conceivable. First, higher

510 densities of dreissenid mussels in Lakes Michigan may enable round gobies to eat a higher total

511 biomass of prey, which causes more total energy to be consumed. Second, the tolerance of

512 round gobies to hypoxia may low enough that they cannot take advantage of the higher densities

513 of non-dreissenid benthic invertebrate prey that are available during mid-July through mid- 
514 October when hypolimnetic oxygen concentrations in central Lake Erie are diminished (see 515 Arend et al. 2011).

Temporal comparisons of alewife ED in Lake Michigan between 2015 and 2002-2004

517 indicated differences in only a few comparisons. One likely explanation for the limited decadal 518 differences is that alewife biomass in 2015 was estimated at only 69 kilotonnes, compared to a 519 mean of 255 kilotonnes in 2002-2004 (D.M. Warner, unpublished data), suggesting reduced 520 intraspecific competition prevented alewife ED from eroding despite declines in offshore total 521 zooplankton biomass and no increases in mysids or Diporeia spp. (Bunnell et al. 2018). The 522 differences that were documented included small alewife ED in November 2015 being $21 \%$ 523 higher than November 2002-2004, and large alewife ED in spring 2015 being 30\% lower in 2015 524 than in spring 2002-2004. The latter difference was consistent with Pothoven and Fahnenstiel 525 (2014) reporting a steeper decline over the first winter of life for yearling alewife in the 2000s 526 than in the 1990s. Given these two studies, we hypothesize that alewives are not able to 527 consume as much energy during winter since 2004 owing to food-web changes. Specifically, 528 during winter and spring when dreissenid mussels can filter more phytoplankton from the water 529 column (Fahnenstiel et al. 2010), this reduction in primary production could reduce the lipids 530 available to overwintering omnivorous copepods that likely sustain alewife as prey overwinter. 531 Several of the Laurentian Great Lakes are undergoing oligotrophication in the offshore 532 waters. As a result, managers are increasingly asking how reductions in nutrients could 533 influence fish production (Bunnell et al. 2018) and adjusting piscivore stocking rates to more 534 accurately balance predator/prey resources. Although the energetic content of alewife and round 535 goby varied across our nine transects, we were unable to explain this variation with the available 536 estimates of their prey density. Whether this lack of correspondence was due to inaccurate 
537 characterization of the prey density at those sites (i.e., sampling on one date in summer and one

538 date in autumn and comparing to autumn condition) or our inability to measure some other

539 important biological factor (e.g., fish movement in and out of sampling sites) is not clear. We

540 also explored whether density dependence could influence condition but correlations between

541 fish density from each transect and residual TE revealed no pattern for either species.

542 Furthermore, lakewide alewife acoustic densities from August 2015 showed higher mean

543 densities in Michigan waters (i.e., along the eastern coastline) than in Wisconsin and Illinois

544 waters (i.e., along the western coastline) by a factor of 1.7 (D.M. Warner, unpublished data),

545 which is the opposite from what we would have predicted if density dependence regulated TE.

546 Future research should explore the eastern versus western shoreline differences in invertebrate

547 prey resources for pelagic-oriented alewife, given the consistently higher TE we measured for

548 large alewife along the eastern transects. These regional differences in alewife condition support

549 the management of Lake Michigan fisheries at a sub-lake level, as is currently being pursued by

550 Michigan Department of Natural Resources.

\section{Acknowledgements:}

553 We thank Tomas Höök for his insightful suggestion to explore relationships with length, in 554 addition to wet weight. Jean Adams provided helpful statistical advice and Chuck Madenjian 555 and two anonymous reviewers provided constructive comments to improve the manuscript. We 556 are grateful for the work by Shawn Parsons, Lyle Grivicich, and Erin Grivicich on the R/V

557 Sturgeon. Research was carried out in accordance with guidelines for the care and use of fishes

558 by the American Fisheries Society. This work was funded by the Great Lakes Restoration 559 Initiation from the Environmental Protection Agency. Benthic surveys of Lake Erie 2014 and 
560 Lake Michigan 2015 were supported by U.S. Geological Survey, Department of the Interior, 561 under USGS Cooperative Agreement No. G14AC000263 to AYK and LEB, "Lake Erie and

562 Lake Michigan Benthos: Cooperative Science and Monitoring Initiative". This is GLERL

563 Contribution No. 1909.

564

565 
566

567

568

569

570

571

572

573

574

575

576

577

578

579

580

581

582

583

584

585

586

587

588

\section{References}

Anderson, N.J., Jeppesen, E., and Søndergaard, M. 2005. Ecological effects of reduced nutrient loading (oligotrophication) on lakes: an introduction. Freshw. Biol. 50: 1589-1593.

Andraso, G.M., Ganger, M.T., and Adamczyk, J. 2011. Size-selective predation by round gobies (Neogobius melanostamus) on dreissenid mussels in the field. J. Great Lakes Res. 37: 298-304. http://dx.doi.org/10.1016/j.jglr.2011.02.006

Anthony, J.A., Roby, D.D., and Turco, K.R. 2000. Lipid content and energy density of forage fishes from the northern Gulf of Alaska. J. Exp. Mar. Biol. Ecol. 248: 53-78.

Arend, K.K., Beletsky, D., DePinto, J.V., Ludsin, S.A., Roberts, J.J., Rucinski, D.K., Scavia, D., Schwab, D.J., and Höök, T.O. 2011. Seasonal and interannual effects of hypoxia on fish habitat quality in central Lake Erie. Freshw. Biol. 56: 366-383.

Brandt, S.B. 1986. Food of trout and salmon in Lake Ontario. J. Great Lakes Res. 12: 200-205.

Bunnell, D.B., Barbiero, R.P., Ludsin, S.A., Madenjian, C.P., Warren, G.J., Dolan, D.M., Brenden, T.O., Briland, R., Gorman, O.T., He, J.X., Johengen, T.H., Lantry, B.F., Lesht, B.M., Nalepa, T.F., Riley, S.C., Riseng, C.M., Treska, T.J., Tsehaye, I., Walsh, M.G., Warner, D.M., and Weidel, B.C. 2014. Changing ecosystem dynamics in the Laurentian Great Lakes: bottom-up and top-down regulation. BioSci. 64: 26-39.

Bunnell, D.B., Davis, B.M., Chriscinske, M.A., Keeler, K.M., and Mychek-Londer, J.G. 2015. Diet shifts by planktivorous and benthivorous fishes in northern Lake Michigan in response to ecosystem changes. J. Great Lakes Res. 41(Suppl. 3): 161-171.

Bunnell, D.B., Carrick, H.J., Madenjian, C.P., Rutherford, E.S., Vanderploeg, H.A., Barbiero, R.P., Hinchey-Malloy, E., Pothoven, S.A., Riseng, C.M., Claramunt, R.M., and eight others. 2018. Are changes in lower trophic levels limiting prey-fish biomass and 
production in Lake Michigan? [online]. Available from: www.glfc.org/pubs/misc/201801.pdf [accessed 24 May 2018].

Davis, B.M., Savino, J.F., and Ogilvie, L.M., 2007. Diet niches of major forage fish in Lake Michigan. Adv. Limnol. 60: 261-275.

Diana, J.S. 1990. Food habits of angler-caught salmonines in western Lake Huron. J. Great Lakes Res. 16: 271-278.

Dietrich, J.P., Morrison, B., and Hoyle, J. 2006. Alternative ecological pathways in the eastern Lake Ontario food web- round goby in the diet of lake trout. J. Great Lakes Res. 32: 395400.

Djuricich, P., and Janssen, J. 2001. Impact of round goby predation on zebra mussel size distribution at Calumet Harbor, Lake Michigan. J. Great Lakes Res. 27: 312-318.

Dolan, D.M., and Chapra, S.C. 2012. Great Lakes total phosphorus revisited: 1. Loading analysis and update (1994-2008). J. Great Lakes Res. 38: 730-740. DOI: 10.1016/j.jglr.2012.10.001

Eggleston, M.A., and Schramm Jr., H.L. 2002. Caloric densities of selected fish prey organisms in the lower Mississippi River. J. Freshw. Ecol. 17: 409-414.

Evans, M.A., Fahnenstiel, G., and Scavia, D. 2011. Incidental oligotrophication of North American Great Lakes. Environ. Sci. Tech. 45: 3297-3303. DOI: 10.1021/es103892w

Fahnenstiel, G., Pothoven, S., Vanderploeg, H., Klarer, D., Nalepa, T., and Scavia, D. 2010. Recent changes in primary production and phytoplankton in the offshore region of southeastern Lake Michigan. J. Great Lakes Res. 36 (Suppl. 3): 20-29. 
610 611

612

613

614

615

616

617

618

619

620

621

622

623

624

625

626

627

628

629

630

631

Fitzsimons, J.D., Clark, M., and Keir, M. 2009. Addition of round gobies to the prey community of Lake Ontario and potential implications to thiamine status and reproductive success of lake trout. Aquat. Ecosystem Health Manage. 12: 296-312.

Forzono, E.M., Crane, D.P., Kapuscinski, K.L., and Clapsadl, M.D. 2017. Dry-weight energy density of prey fishes from nearshore waters of the upper Niagara River and Buffalo Harbor, New York. J. Great Lakes Res. 43: 215-220.

Gorman, K.B., Kline Jr., T.C., Roberts, M.E., Sewall, F.F., Heintz, R.A., and Pegau, W.S. 2018. Spatial and temporal variation in winter condition of juvenile Pacific herring (Clupea pallasii) in Prince William Sound, Alaska: Oceanographic exchange with the Gulf of Alaska. Deep-Sea Res. Part II 147: 116-126.

Happel, A., Creque, S., Rinchard, J., Höök, T., Bootsma, H., Janssen, J., Jude, J., and Czesny, S. 2015a. Exploring yellow perch diets in Lake Michigan through stomach content, fatty acids, and stable isotope ratios. J. Great Lakes Res. 41(Suppl. 3): 172-178.

Happel, A., Lafountain, J., Creque, S., Rinchard, J., Höök, T., Bootsma, H., Janssen, J., Jude, J., and Czesny, S. 2015b. Spatio-temporal description of spottail shiner (Notropis hudsonius) fatty acid profiles in Lake Michigan's southern basin. J. Great Lakes Res. 41(Suppl. 3): 179-184.

Happel, A., J. L. Jonas, P. R. McKenna, J. Rinchard, J. X. He, and S. J. Czesny. 2018. Spatial variability of lake trout diets in Lakes Huron and Michigan revealed by stomach content and fatty acid profiles. Can. J. Fish. Aquat. Sci. 75:95-105.

Hartman K.J., and Brandt, S.B. 1995. Estimating energy density of fish. Trans. Amer. Fish. Soc. 124: 347-355. 
632 Hewett, S.W., and Johnson, B.L. 1992. Fish bioenergetics model 2: an upgrade of a generalized

633

634

635

636

637

638

639

640

641

642

643

644

645

646

647

648

649

650

651

652

653

bioenergetics model of fish growth for microcomputers. University of Wisconsin, Sea Grant Technical Report WIS-SG-92-250.

Hilborn, R., and Walters, C.J. 1992. Quantitative fisheries stock assessment: choice, dynamics, and uncertainty. Chapman and Hall, New York.

Hondorp, D.W., Pothoven, S.A., and Brandt, S.B. 2005. Influence of Diporeia density on diet composition, relative abundance, and energy density of planktivorous fishes in southeast Lake Michigan. Trans. Amer. Fish. Soc. 134: 588-601.

Jacobs, G.R., Madenjian, C.P., Bunnell, D.B., Warner, D.M., and Claramunt, R.M. 2013. Chinook salmon foraging pattern in a changing Lake Michigan. Trans. Amer. Fish. Soc. 142: $362-372$.

Janssen, J., and Brandt, S.B. 1980. Feeding ecology and vertical migration of adult alewives (Alosa pseudoharengus) in Lake Michigan. Can. J. Fish. Aquat. Sci. 37:177-184.

Janssen, J., Berg, M.B., and Lozano, S.J. 2005. Submerged terra incognita: Lake Michigan’s abundant but unknown rocky zones. Pages 113-139 in State of Lake Michigan: Ecology, Health, and Management. Edited by T. Edsall and M. Munawar. Ecovision World Monograph Series, Aquatic Ecosystem Health and Management Society.

Johnson, T.B., Bunnell, D.B., and Knight, C.T. 2005. A potential new energy pathway in central Lake Erie: the round goby connection. J. Great Lakes Res. 31(Suppl. 2): 238-251.

Juanes, F. 1994. What determines prey size selectivity in piscivorous fishes? In Theory and application of fish feeding ecology. Edited by D.J. Stouder, K.L. Fresh, and R.J. Feller. University of South Carolina Press, Columbia, South Carolina. pp. 79-100. 
654 Jude, D.J., Tesar, F.J., Deboe, S.F., and Miller, T.J. 1987. Diet and selection of major prey 655 species by Lake Michigan salmonines, 1973-1982. Trans. Amer. Fish. Soc. 116: 677656 691.

657 Karatayev, A.Y., Burlakova, L.E., Mehler, K., Bocaniov, S.A., Collingsworth, P.D., Warren, G., 658 659 660 661 662 predators in the northwest Atlantic: proximate composition and energy density. Mar. Kraus, R.T., and Hinchey, E.K. 2018. Biomonitoring using invasive species in a large lake: Dreissena distribution maps hypoxic zones. J. Great Lakes Res. 44: 639-649. https://doi.org/10.1016/j.jglr.2017.08.001

Karatayev, A.Y., and Burlakova, L.E. 2017. Lake Erie and Lake Michigan benthos: Cooperative Science and Monitoring Initiative. Final Report. USGS-GLRI G14AC00263. Great Lakes Center, SUNY Buffalo State, Buffalo, NY. Available at: http://greatlakescenter.buffalostate.edu/sites/greatlakescenter.buffalostate.edu/files/uplo ads/Documents/Publications/LakeErieandMichiganBenthos_CSMI20142015 FinalReport.pdf

Kornis, M.S., Mercado-Silva, N., and Vander Zanden, M.J. 2012. Twenty years of invasion: a review of round goby Neogobius melanostomus biology, spread, and ecological implications. J. Fish Biol. 80: 235-285.

Lambert, Y., and Dutil, J.D. 1997. Condition and energy reserves of Atlantic cod (Gadus morhua) during the collapse of the northern Gulf of St. Lawrence stock. Can. J. Fish. Aquat. Sci. 54: 2388-2400. DOI: 10.1139/cjfas-54-10-2388

Lawson, J.W., Magalhães, and Miller, E.H. 1998. Important prey species of marine vertebrate Ecol. Prog. Ser. 164: 13-20. 
676 Madenjian, C.P., Desorcie, T.J., and Stedman, R.M. 1998. Ontogenetic and spatial patterns in

677

678

679

680

681

682

683

684

685

686

687

688

689

690

691

692

693

694

695

696

697

698

diet and growth of Lake Trout in Lake Michigan. Trans. Amer. Fish. Soc. 127: 236-252.

Madenjian, C.P., Pothoven, S.A., Dettmers, J.A., and Holuszko, J.D. 2006. Changes in seasonal energy dynamics of alewife (Alosa pseudoharengus) in Lake Michigan after invasion of dreissenid mussels. Can. J. Fish. Aquat. Sci. 63: 891-902. DOI: 10.1139/F06-017

Nalepa, T.F., Hartson, D.J., Buchanan, J., Cavaletto, J.F., Lang, G.A., and Lozano, S.J. 2001. Spatial variation in density, mean size and physiological condition of the holarctic amphipod Diporeia spp. in Lake Michigan. Freshwater Biol. 43: 107-119.

Nalepa, T.F., Fanslow, D.L., Lang, G.A., Mabrey, K., and Rowe, M. 2014. Lake-wide benthic surveys in Lake Michigan in 1994-95, 2000, 2005, and 2010: Abundances of the amphipod Diporeia spp. and abundances and biomass of the mussels Dreissena polymorpha and Dreissena rostriformis bugensis. NOAA Technical Memorandum GLERL-164. NOAA, Great Lakes Environmental Research Laboratory, Ann Arbor, MI. https://www.glerl.noaa.gov/pubs/tech_reports/glerl-164/tm-164.pdf

Pangle, K.L., Sutton, T.M., Kinnunen, R.E., and Hoff, M.H. 2004. Overwinter survival of juvenile lake herring in relation to body size, physiological condition, energy stores, and food ration. Trans. Amer. Fish. Soc. 133: 1235-1246. DOI: 10.1577/T03-127.1

Paul, A.J., and Paul, J.M. 1999. Interannual and regional variations in body length, weight, and energy content of age-0 Pacific herring from Prince William Sound, Alaska. J. Fish Biol. 54: 996-1001.

Plattner, S., Mason, D.M., Leshkevich, G.A., Schwab, D.J., and Rutherford, E.S. 2006. Classifying and forecasting coastal upwellings in Lake Michigan using satellite derived temperature images and buoy data. J. Great Lakes Res. 32: 63-76. 
699

700

701

702

703

704

705

706

707

708

709

710

711

712

713

714

715

716

717

718

719

720

Pothoven, S.A., and Fahnenstiel, G.L. 2013. Recent change in summer chlorophyll a dynamics of southeastern Lake Michigan. J. Great Lakes Res. 39: 287-294. DOI: 10.1016/j.jglr.2013.02.005

Pothoven, S.A., and Fahnenstiel, G.L. 2014. Declines in the energy content of yearling nonnative alewife associated with lower food web changes in Lake Michigan. Fish. Manage. Ecol. 21: 439-447.

Pothoven, S.A., and Madenjian, C.P., 2008. Changes in consumption by alewives and lake whitefish after dreissenid mussel invasions in lakes Michigan and Huron. N. Am. J. Fish Manag. 28: 308-320.

Pothoven, S.A., Bunnell, D.B., Madenjian, C.P., Gorman, O.T., and Roseman, E.F. 2012. Energy density of bloaters in the upper Great Lakes. Trans. Amer. Fish. Soc. 141: 772-780. DOI: $10.1080 / 00028487.2012 .675911$

Rand, P.S., Lantry, B.F., O'Gorman, R., Owens, R.W., and Stewart, D.J. 1994. Energy density and size of pelagic prey fishes in Lake Ontario, 1978-1990: implications for salmonine energetics. Trans. Amer. Fish. Soc. 123: 59-534.

Rand, P.S., Stewart, D.J., Lantry, B.F., Rudstam, L.G., Johannsson, O.E., Goyke, A.P., Brandt, S.B., O'Gorman, R., and Eck, G.W. 1995. Effect of lakewide planktivory by the pelagic prey fish community in lakes Michigan and Ontario. Can. J. Fish. Aq. Sci. 52: 15461563.

Rennie, M.D., Sprules, W.G., and Johnson, T.B. 2009. Factors affecting the growth and condition of lake whitefish (Coregonus clupeaformis). Can. J. Fish. Aq. Sci. 66: 20962108. 
721 Riley, S.C., Roseman, E.F., Nichols, S.J., O’Brien, T.P., Kiley, C.S., and Schaeffer, J.S. 2008.

722

723

724

725

726

727

728

729

730

731

732

733

734

735

736

737

738

739

740

741

742

743

Deepwater demersal fish community collapse in Lake Huron. Trans. Amer. Fish. Soc. 137: $1879-1890$.

Robertson, D.M., Hubbard, L.E., Lorenz, D.L., and Sullivan, D.J. 2018. A surrogate regression approach for computing continuous loads for the tributary nutrient and sediment monitoring program on the Great Lakes. J. Great Lakes Res. 44: 26-42.

Roseman, E.F., Schaeffer, J.S., Bright, E., and Fielder, D.G. 2014. Angler-caught piscivore diet reflect fish community changes in Lake Huron. Trans. Amer. Fish. Soc. 143: 1419-1433.

Ruetz, C.R., Strouse, D.L., and Pothoven, S.A. 2009. Energy density of introduced round goby compared with four native fishes in a Lake Michigan tributary. Trans. Amer. Fish. Soc. 138: 938-947. DOI: 10.1577/T08-048.1

Stockner, J.G., Rydin, E., and Hyenstrand, P. 2000. Cultural oligotrophication: causes and consquences for fisheries resources. Fisheries 25(5): 7-14.

Stewart, D.J., and Binkowski, F.P. 1986. Dynamics of consumption and food conversion by Lake Michigan alewives- an energetics modeling synthesis. Trans. Amer. Fish. Soc. 115: 643-661.

U.S. Department of Interior, U.S. Fish and Wildlife Service and U.S. Department of Commerce, U.S. Census Bureau. 2016. National survey of fishing, hunting, and wildlife-associated recreation. Report Number: FHW/16-NAT. [online]. Available from: https://www.census.gov/library/publications/2018/demo/fhw-16-nat.html [accessed 11 July 2018].

Walsh, M.G., Dittman, D.E. and O'Gorman, R. 2007. Occurrence and food habits of the round goby in the profundal zone of southwestern Lake Ontario. J. Great Lakes Res. 33: 83-92. 
744 Wanless, S., Harris, M.P., Redman, P., and Speakman, J.R. 2005. Low energy values of fish as a 745 probable cause of a major seabird breeding failure in the North Sea. Mar. Ecol. Prog. Ser. 294: 1-8. 
747 Table 1. Predictive relationship between energy density (ED, kJ/g wet mass) and percent dry

748 weight $(\% \mathrm{DW})$ for alewife and round goby collected from Lake Michigan during 2015.

\begin{tabular}{lllll}
\hline Species & Size Class & Equation & $\mathrm{N}$ & Statistics \\
\hline Alewife & Small $(\leq 120$ & $\mathrm{ED}=-1.931+0.331(\% \mathrm{DW})$ & 220 & $F=6407.7$ \\
& $\mathrm{~mm}, \mathrm{TL})$ & & & $P<0.0001$ \\
& & & 362 & $r^{2}=0.97$ \\
Alewife & Large $(>120$ & $\mathrm{ED}=-3.143+0.370(\% \mathrm{DW})$ & & $P<0.0001$ \\
& $\mathrm{~mm}, \mathrm{TL})$ & & & $r^{2}=0.97$ \\
& & $\mathrm{ED}=-0.326+0.228(\% \mathrm{DW})$ & 585 & $F=2362.0$ \\
Round goby & $\mathrm{n} / \mathrm{a}$ & & & $P<0.0001$ \\
& & & & $r^{2}=0.80$ \\
\hline
\end{tabular}


751 Figure 1. Location of sampling sites with adjacent tributaries that were sampled in Lake

752 Michigan in 2015. Inset shows where Lake Michigan is located among the Laurentian Great 753 Lakes. Map data: ArcGIS and U.S. Geological Survey.

Figure 2. Comparison of round goby and alewife weight (a) and energy density (b, estimated 756 directly from bomb calorimetry or calculated from $\%$ dry weight) as a function of total length 757 based on samples collected from nine transects in Lake Michigan from 2015. Large seasonal 758 differences in alewife energy density were apparent in panel b.

759

Figure 3. Total energy of alewife (left column) and round goby (right column) as a function of total length. Panels a, b represent fish sampled between April 16 and May 11. Panels c, d represent fish sampled between July 18-26. Panels e, f represent fish sampled between October

76318 and November 3. The line represents predicted total energy for a given total length. The 764 coefficient of determination for the relationship and the number of transects from which fish 765 were sampled are shown in each panel.

766

767 Figure 4. The mean residual (observed-predicted, in ln-scale) total energy for small (left column, $768 \leq 120 \mathrm{~mm}$ ) and large (right column, $>120 \mathrm{~mm}$ ) alewife size classes sampled in eight transects in 769 Lake Michigan in 2015 (noting that alewives were not sampled in all transects in all seasons). 770 Abbreviations for transects [ordered left to right as western shoreline (north to south) and then 771 eastern shoreline (north to south)] are STB (Sturgeon Bay), MNW (Manitowoc), RT (Root), WK 772 (Waukegan), FF (Frankfort), PM (Pere Marquette), MK (Muskegon), and STJ (St. Joseph).

773 Panels a, b represent alewife sampled between April 16 and May 11. Panel $\mathrm{c}$ represents alewife 
774 sampled between July 18-26. Panels d, e represent alewife sampled between October 18 and

775 November 3. Small alewives were not collected in summer. Different letters indicate the mean

776 residuals are significantly different from one another.

777

778 Figure 5. The mean residual (observed-predicted, in ln-scale) total energy for small (left column,

$779 \leq 70 \mathrm{~mm}$ ) and large (right column, $>70 \mathrm{~mm}$ ) round goby size classes sampled in nine transects in

780 Lake Michigan in 2015 (noting that round gobies were not sampled in all transects in all

781 seasons). Abbreviations for transects [ordered left to right as western shoreline (north to south)

782 and then eastern shoreline (north to south)] are STB (Sturgeon Bay), MNW (Manitowoc), RT

783 (Root), WK (Waukegan), FF (Frankfort), PM (Pere Marquette), MK (Muskegon), KZ

784 (Kalamazoo), and STJ (St. Joseph). Panels a, b represent round goby sampled between April 16

785 and May 11. Panel c represents round goby sampled between July 18-26. Panels d, e represent

786 round goby sampled between October 18 and November 3. Small round gobies were not

787 collected in summer. Different letters indicate the mean residuals are significantly different from

788 one another.

789

790 Figure 6. Temporal comparisons for large alewife energy density in Lake Michigan. Panel a

791 illustrates the monthly mean energy density ( $\pm 95 \%$ confidence intervals, where available $)$ over

792 three time periods, with 1979-1981 and 2002-2004 values derived from Madenjian et al. (2006).

793 Note that November 2015 represents alewives sampled between 26 October and 3 November.

794 Panel $b$ depicts the percent difference in large alewife energy density between the mean of 2015

795 and 2002-2004 values and the mean 1979-1981 value. 
797 Figure 7. Comparisons between round goby energy density (estimated through bomb 798 calorimetry) as a function of wet weight estimated from nine transects in Lake Michigan in 2015 799 (data are open gray circles; dashed, dark gray line is the best fit curve) to those from Muskegon 800 watershed (dashed line, Ruetz et al. 2009), Lake Huron in 2007 (solid line) and central Lake Erie 801 (dash-dot-dot-dash line, Johnson et al. 2005).

802 
Figure 1.

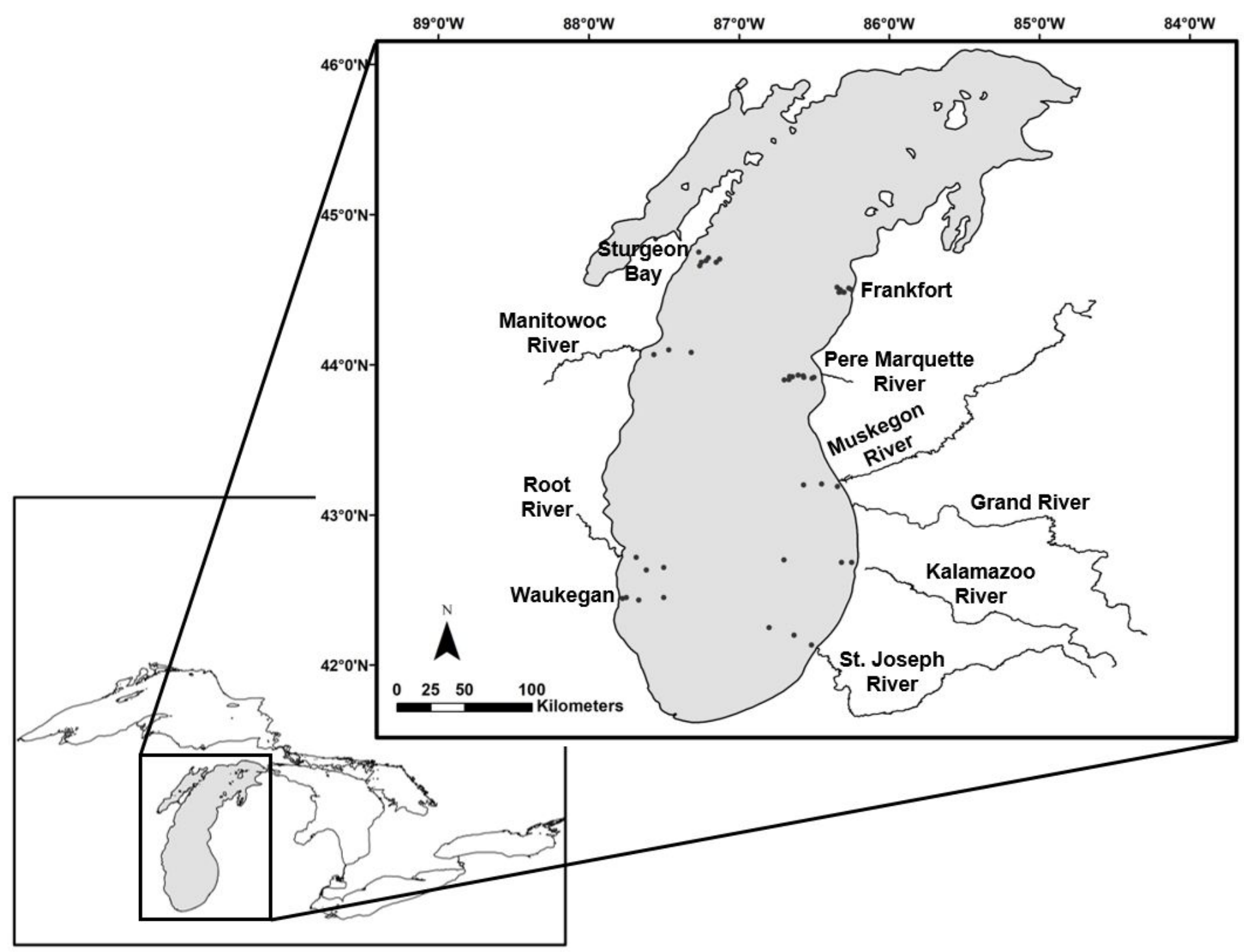


Figure 2.

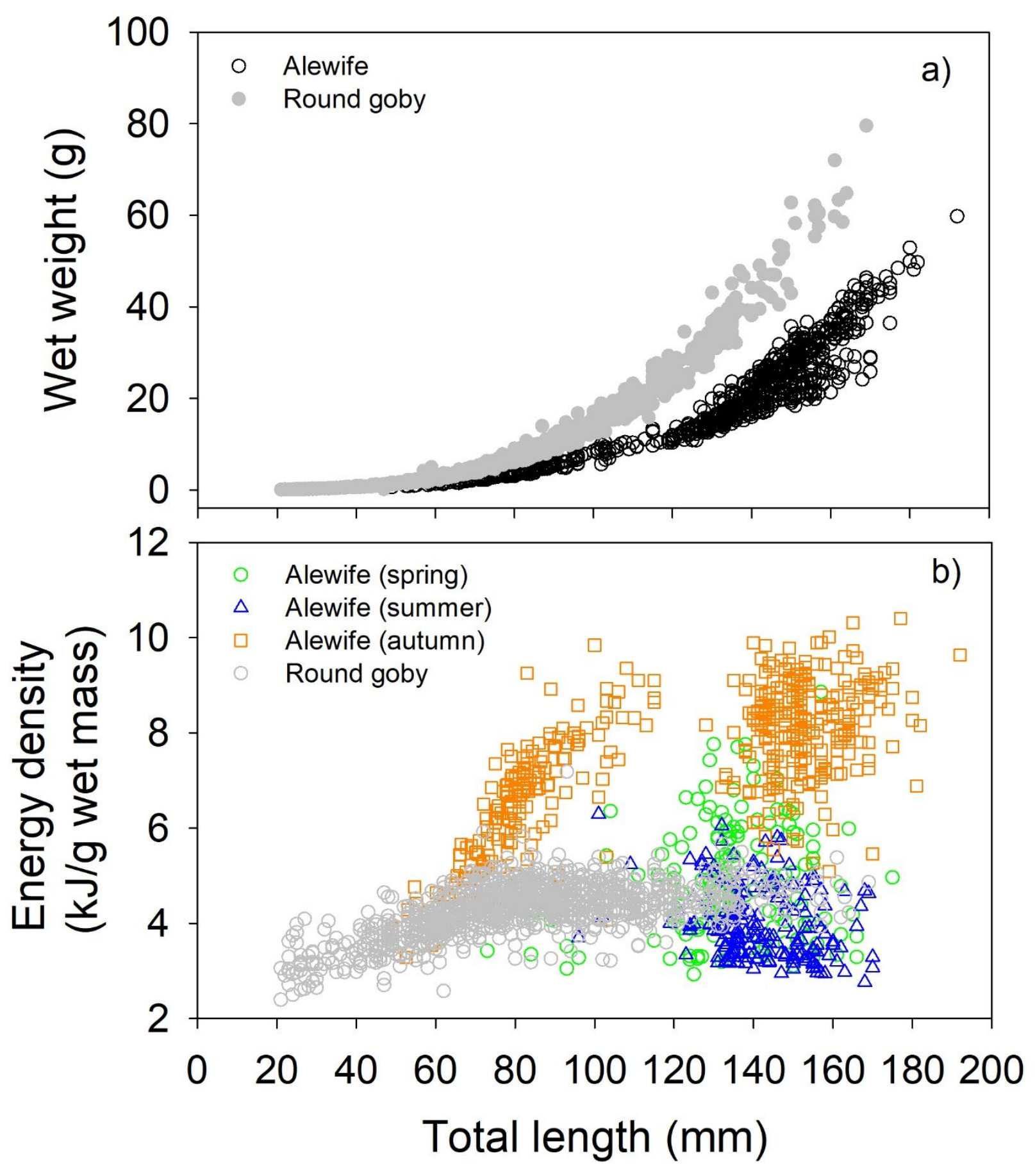


Figure 3.

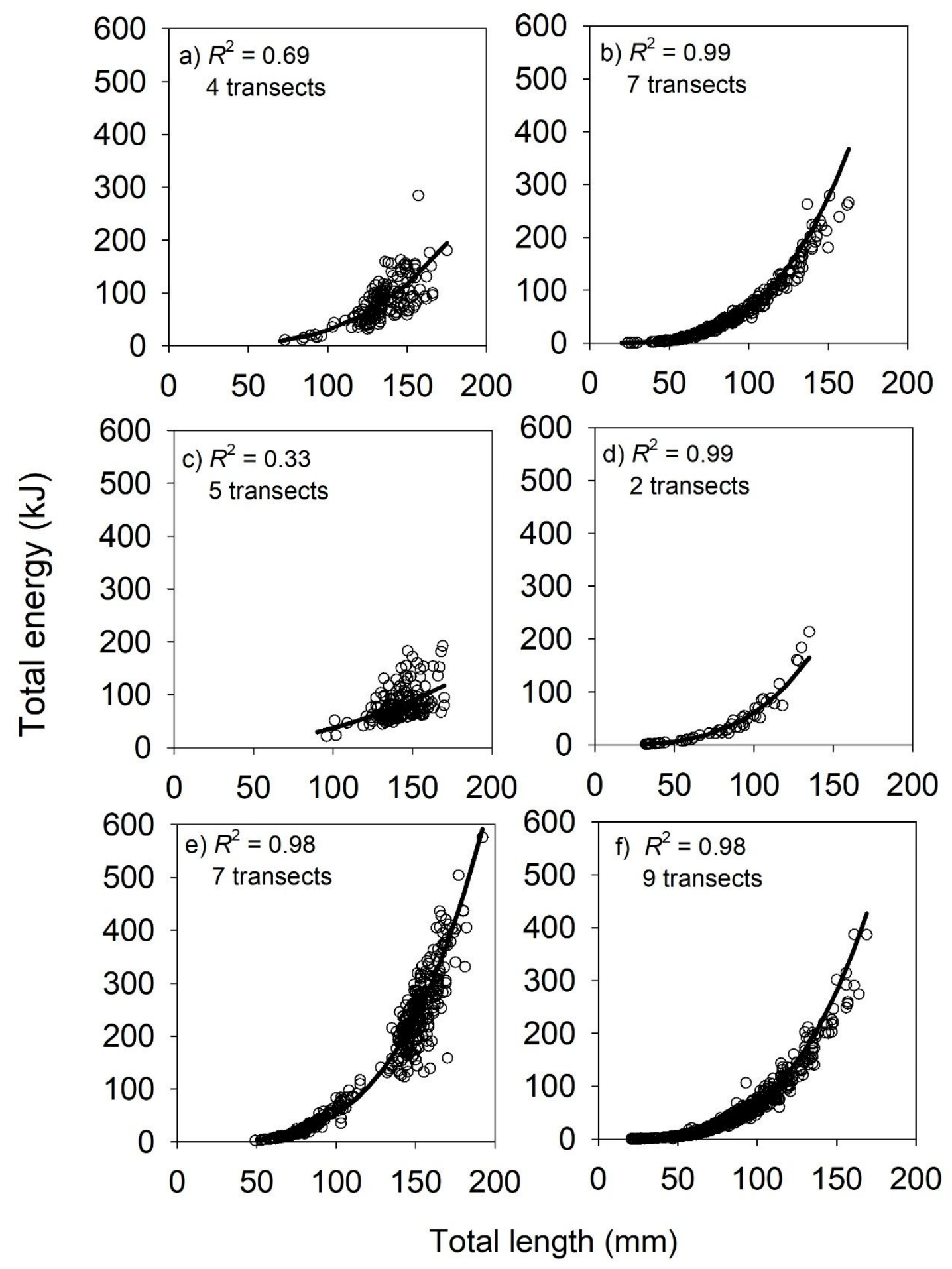


Figure 4.

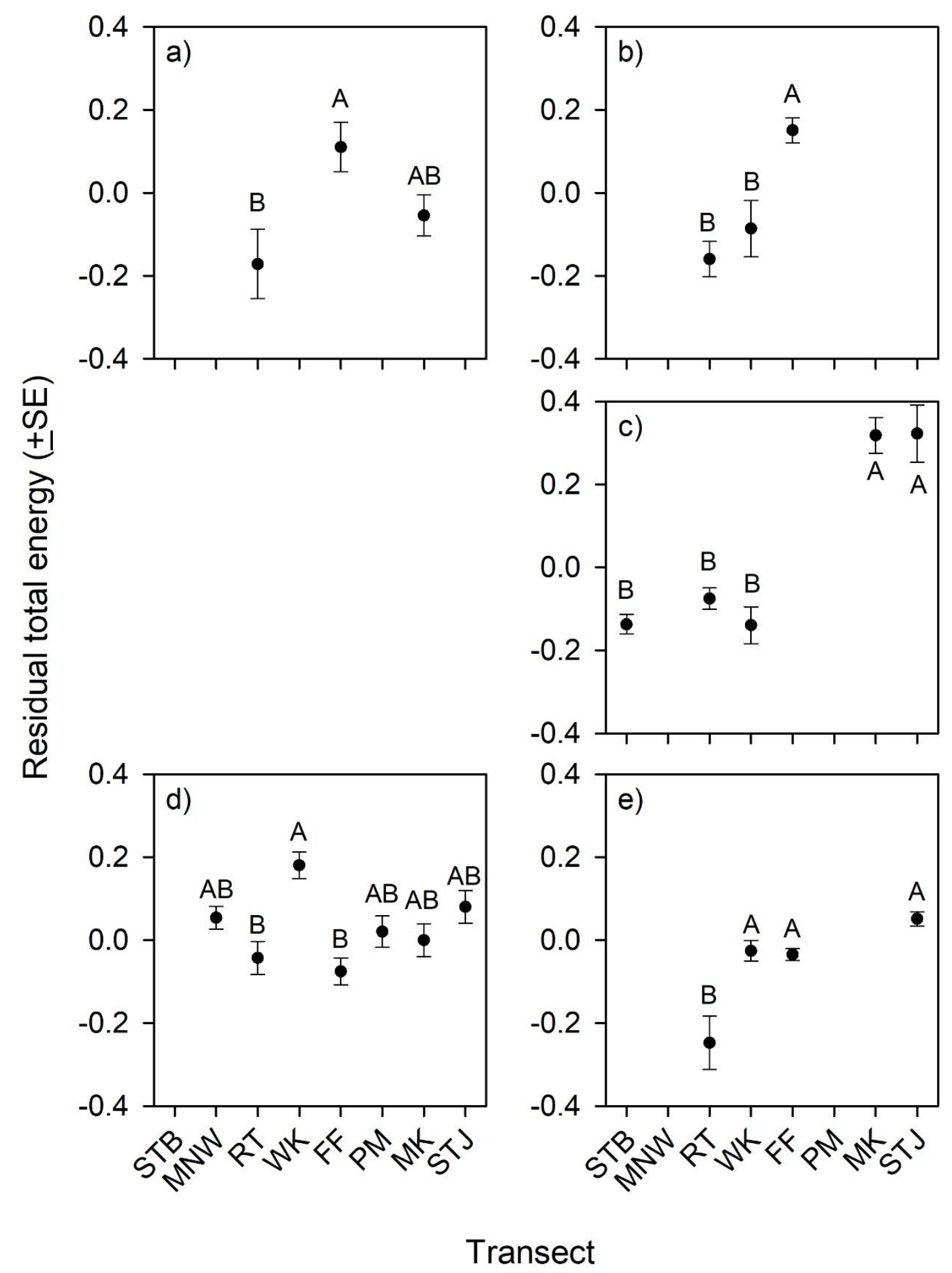


Figure 5.

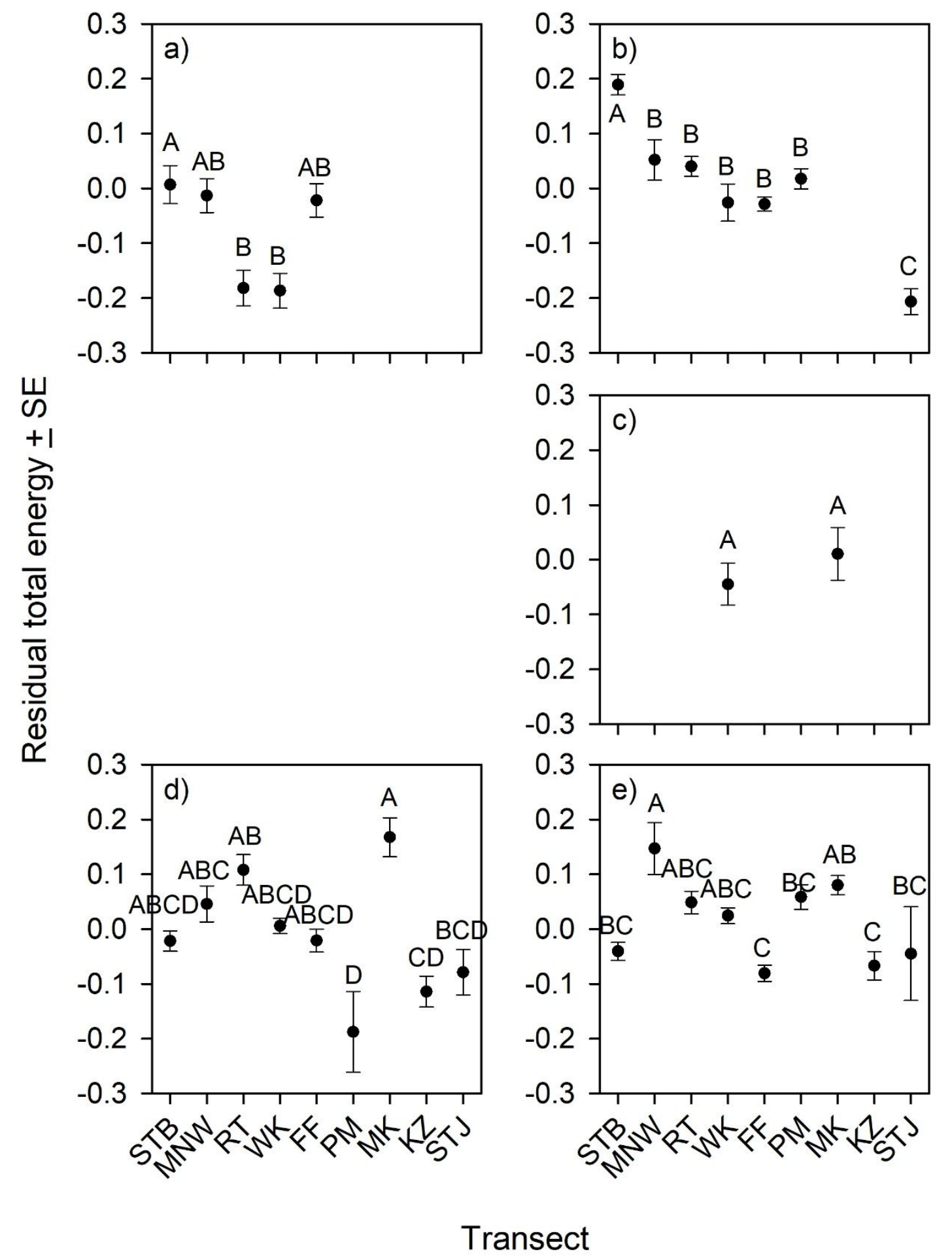


Figure 6.

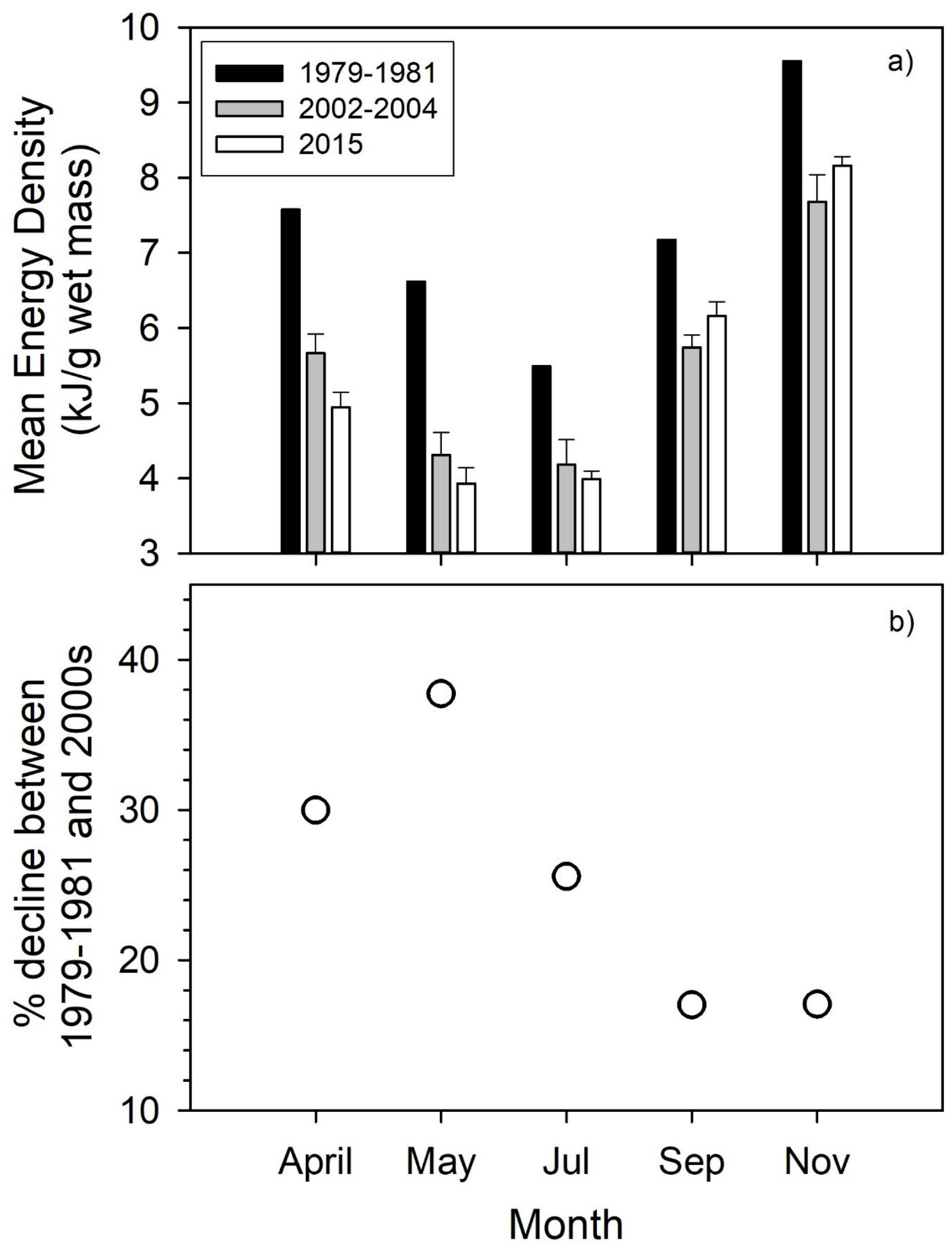


Figure 7.

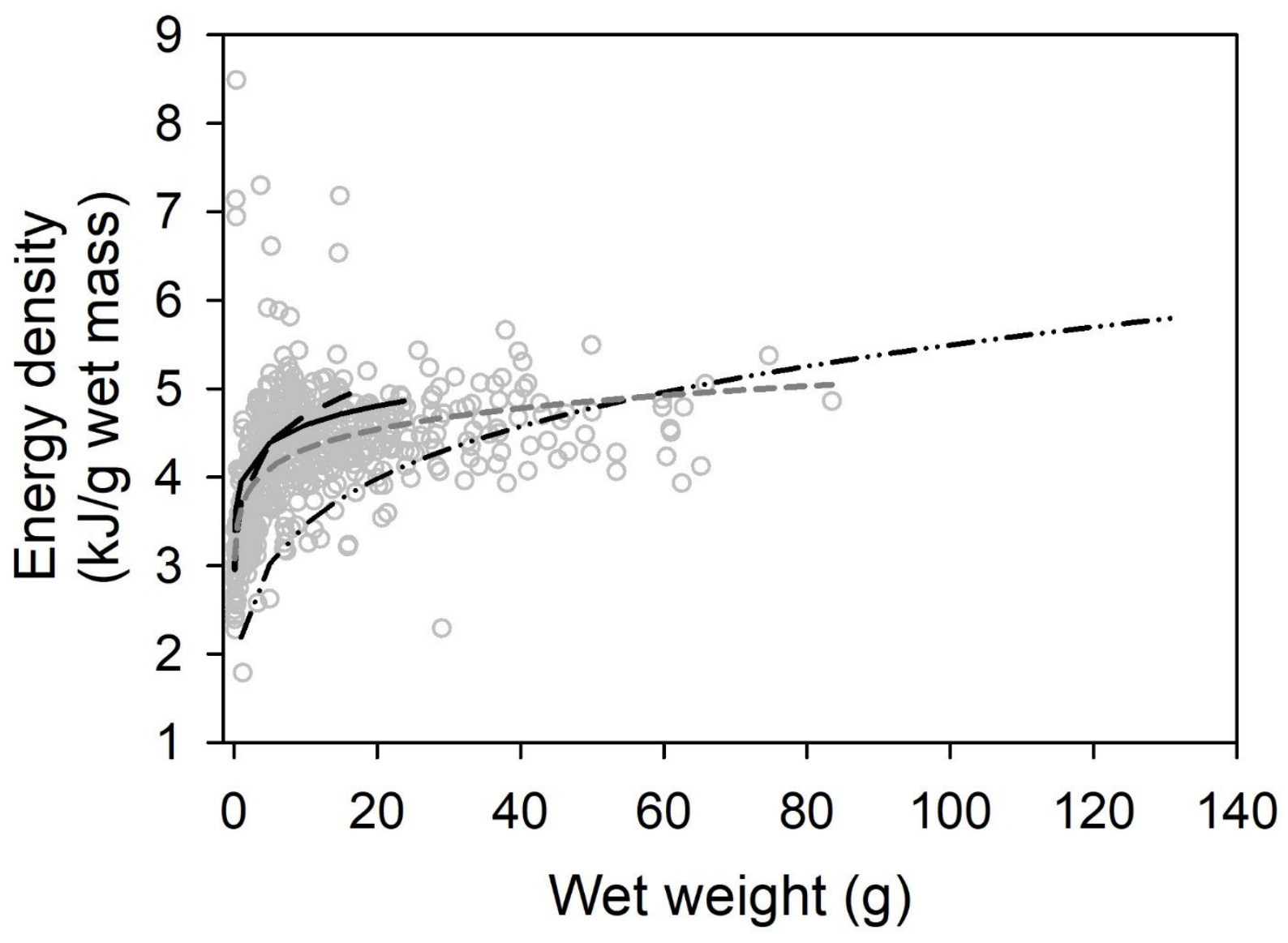

